\title{
US physicists rally to save standards agency
}

Washington. The US science establishment has launched a campaign to save the National Institute of Science and Technology (NIST), which is looking increasingly vulnerable as Congress moves to close its parent agency, the Department of Commerce.

Twenty-five US recipients of the Nobel prize for physics wrote to Congressional leaders this week to emphasize the "essential role to the nation" of the NIST laboratories at Boulder, Colorado and Gaithersburg, Maryland. They were joined by the heads of eighteen major scientific groupings, led by the American Physical Society.

One of the Nobelists, Norman Ramsey of Harvard University, described NIST as "a great institution". He cited the first demonstration of Bose-Einstein condensation, at Boulder earlier this summer, as an example of the quality of the work of its laboratories.

A new bill aimed at abolishing the commerce department was introduced into the Senate last week by William Roth (Republican, Delaware), and passed through the Senate's government affairs committee, which he chairs.

The measure, which has considerable momentum in the upper house, would transfer the standards functions of NIST to a new Office of Patents, Trademarks and Standards. It makes no provision for the NIST laboratories, which employ around 3200 people in support of its standards work.

Many scientists are worried that Congress will overlook the laboratories as it rushes to close down the large extramural technology programmes which NIST also operates (see Nature 376, 453; 1995), and to dismantle the Department of Commerce, headed by the flamboyant former Congressman, Ron Brown. The department has emerged as the prime candidate for abolition in a Republican Congress that is keen to prove its radicalism by shutting down at least one government department.

A bill introduced into the House in June by Dick Chrysler (Democrat, Michigan) would transfer NIST's functions into the National Science Foundation (NSF). But critics point out that the NSF is a grant-giving body with no laboratories of its own, and no known desire to accrue any.

As well as the Bose-Einstein breakthrough, NIST laboratories have pioneered the development of magnetic microscopes, and standards and test methods for modern, digital communications networks. They also house the world's most accurate atomic clock, NIST-7, as well as the most heavily used neutron source in the United States, the Cold Neutron Research Facility at Gaithersburg.

So far this year, the US scientific establishment has concentrated most of its lobbying efforts on a hitherto successful effort to defend the budgets of the National Insti-

tutes of Health and the NSF, the two main grant-giving agencies in the federal government. As a result, Monday's plea by the Nobel laureates and scientific societies arrives perilously late in the day for NIST.

But scientific leaders are alarmed that proposals to disband the commerce department are about to be absorbed into a "reconciliation bill" which Congress will

\& place on President Bill Clinton's desk $\stackrel{\infty}{\times}$ in mid-November.

\section{IMAGE \\ UNAVAILABLE FOR COPYRIGHT REASONS}

Brown: destined to lose his department?

ơ This vast bill will attempt to reconcile all federal spending and taxation. According to Michael Lubell, director of public affairs at the American Physical Society, NIST's $\$ 250$ million inter-

nal research programme could easily be "lost in the noise" surrounding it.

"As Congress prepares the omnibus reconciliation bill, its ignorance of NIST laboratory functions could easily result in actions that would cause irreparable harm to a vital government research activity, however unintended that harm might be," says Lubell.

Meanwhile a Senate appropriations subcommittee has approved a budget of $\$ 223$ million to run the NIST laboratories next year, compared to $\$ 276$ million proposed by the House and $\$ 311$ million requested by Clinton. The Senate bill would also provide NIST with $\$ 76$ million to wind down its technology support programmes, against nothing from the House and Clinton's request of $\$ 640$ million to continue the programme.

Arati Prabhakar, the director of NIST, says the Senate figure for technology support is "totally unacceptable". Cuts in the laboratories' budgets will "pose some significant challenges," but are "not the sort of catastrophe" facing other programmes in the same bill, she says.

Prabhakar enthusiastically welcomed the scientists' expression of support for her laboratories. But the scientists have not been able to suggest a safe home for NIST if the commerce department is indeed shut down.

Robert Walker (Republican, Pennsylvania), chair of the House science committee, was set to put forward his proposed Department of Science as such a home at hearings on the Chrysler bill due this week. But Nobel laureate Robert Schrieffer of Florida State University says that the community is "close to unanimity" in rejecting that idea.

Scientific leaders add that there is no serious case to be made for a shotgun marriage with the NSF. The best hope for NIST now may be a period of uncomfortable limbo until the November 1996 presidential election. This is precisely what it will get if Congress abolishes the Commerce Department in a reconciliation bill which President Clinton then sees fit to veto. Colin Macilwain

\section{Neuroscientists seek meeting boost}

Munich. The heads of 17 national neuroscience associations agreed last week to coordinate their activities more closely with those of the European Neuroscience Association (ENA), partly to raise attendance at ENA's annual meeting.

Between 15,000 and 20,000 participants - including several thousand European neuroscientists - regularly take part in the neuroscience meeting held every November in the United States and organized by the US Society for Neuroscience. In contrast, its European equivalent, held two months earlier, seldom attracts 2000 participants.

One major reason is cost; it is often cheaper to cross the Atlantic than to travel within Europe, and the large attendance at the US meeting means that registration fees can be kept low. But the European association also has to compete with national neuroscience meetings, which are also less expensive to attend.

To help solve both problems, the national bodies agreed in Amsterdam last week to study ways of moving towards a federal structure within ENA, and to coordinate the timing of their meetings with those of the
European body, to avoid direct competition. According to Wolf Singer, head of neurophysiology at the Max Planck Institute of Brain Research in Frankfurt, and president of ENA, the European body proposed moving its own meeting from September to June to avoid clashing with the US meeting, starting in 1997 or 1998.

ENA - which is planning to approach the European Commission for financial support - suggests it should in future also hold its own meeting only every other year, alternating with national meetings. Singer says this is intended to increase the number of participants, and so reduce registration fees.

In turn, national societies' delegates have agreed to consider ways of coordinating their own meetings with this timetable. They will continue to meet on their own every two years, but will try to combine their meetings with that of the ENA in alternate years.

In contrast to the European body, national neuroscience organizations continue to attract relatively high numbers of participants. A final decision on the future structure of the ENA meetings will be made at its 1996 meeting in Strasbourg. Alison Abbott 